\author{
Piotr Roszak ${ }^{1}$
}

Uniwersytet Mikołaja Kopernika w Toruniu

\title{
Mozarabowie a iberyjskie doświadczenie graniczności
}

Przy rozważaniach nad multikulturalizmem współczesnego świata, gdy w kontekście wielokierunkowej globalizacji rodzą się pytania o naturę powszechnie odczuwalnej wielobiegunowości i jej konsekwencji, warto przyjrzeć się pewnym doświadczeniom historycznym, które mogą wnieść ciekawe przemyślenia do aktualnych debat z tego zakresu. Takim ciekawym przykładem mogą stać się mozarabowie, którzy na południu Półwyspu Iberyjskiego, mocno arabizowanym po inwazji z 711 roku, potrafili jednak ocalić swoją chrześcijańską tożsamość ${ }^{3}$. Żyją w silnie spolaryzowanym świecie (w którym wydaje się, że tertium non datur), a jednak ich sposób życia (i zasługi dla chrześcijaństwa hiszpańskiego) jako „nieugiętej mniejszości”, która zgodziła się na utratę własnej kultury, ale ją jeszcze pogłębiła, żyjąc w morzu kul-

1 Piotr Roszak - doktor hab. teologii; adiunkt w Zakładzie Teologii Fundamentalnej i Religiologii Wydziału Teologicznego UMK w Toruniu; profesor stowarzyszony teologii dogmatycznej Uniwersytetu Nawarry w Pampelunie (Hiszpania); red. naczelny czasopisma „Scientia et Fides” oraz redaktor serii wydawniczej „Scholastica Thoruniensia”, w której zamieszczane są tłumaczenia komentarzy biblijnych średniowiecznych autorów.

2 W artykule wykorzystano informacje zdobyte w ramach realizowanego projektu „Chrystus vs. Mahomet. Chrystologia mozarabska w świetle źródeł liturgicznych rytu hiszpańskiego” sfinansowanego ze środków Narodowego Centrum Nauki przyznanych na podstawie decyzji numer DEC-2011/01/D/HS1/00712.

3 Por. R. Hitchcock, Mozarabs in medieval and early modern Spain: identities and influences, Burlington 2008, s. 25nn. 
tury arabskiej, odsłania istotną prawdę o wielokulturowości i jej mechanizmach, zwłaszcza w odniesieniu do podtrzymywania własnej tożsamości Nie jest to relacja nacechowana ekskluzywizmem czy absolutyzacją jednego „kosztem” drugiego, ale skierowaniem uwagi na szacunek dla otrzymanego dziedzictwa, które nas ukształtowało, co przekłada się na troskę o „kulturę pamięci”. Termin ten chciałbym przybliżyć, opierając się na doświadczeniu mozarabskim, odległym od nas o tysiące kilometrów, a jednocześnie tak bardzo bliskim ze względu na nasze polskie losy narodowe.

\section{Z perspektywy Finisterre: plus ultra, czyli o kulturze nadziei i pamięci}

Finisterra (vel Fisterra) to niewielki półwysep na zachodnich krańcach Półwyspu Iberyjskiego, gdzie w średniowieczu znajdował się znamienny napis - non plus ultra ${ }^{5}$, który miał za zadanie informować, że w tym miejscu kończy się świat. Dalej nie ma już nic. Ale dla mieszkańców Iberii miało to jeszcze inne konsekwencje, w jakiejś mierze paradygmatyczne dla naszej refleksji nad multikulturalizmem: przypominało wydarzenie tak ważne dla tożsamości mieszkańców półwyspu, mianowicie misję apostoła Jakuba, który dotarł na „krańce świata”, by wypełnić zadanie postawione w Dziejach Apostolskich (Dz 1, 8) $)^{6}$. Owo znajdowanie się „na granicy światów” inspiro-

4 Por. M. Diaz, Los mozárabes. Una minoría combativa, [w:] C. Aillet, M. Penelas, P. Roisse, ¿Existe una identidad mozárabe? Historia, lengua y cultura de los cristianos de al-Andalus (siglos IX-XII), Madrid 2008, s. 7-8.

5 P. Roszak, Plus ultra dla nadziei, czyli o duchu hiszpańskości, „Recogito” 49 (2008), www.recogito.pologne.net/recogito_49/wiara5.htm (24.03.2012).

6 Najnowsze badania archeologiczne i paleograficzne prowadzone przez prof. Enrique Alarcona z Uniwersytetu Nawarry w Pampelunie dotyczące napisu „Iacob” znajdującego się wewnątrz grobu przypisywanego apostołowi Jakubowi, ze względu na unikatowe nawiązania do chryzmonu jerozolimskiego i języka hebrajskiego zdają się potwierdzać tezy - do tej pory traktowane jako niepotwierdzona tradycja średniowieczna - mówiące o autentyczności grobu św. Jakuba w Hiszpanii. Wielowiekowe milczenie (do czasu tzw. inventio, odkrycia grobu przez mnicha o imieniu Pelaio z VIII w.) zyskuje na zrozumiałości, jeśli uwzględnić skomplikowany czas prześladowań i późniejszych zagrożeń militarnych w Galicji. Por. E. Alarcón, Sepulcrum Iacobi, [w:] P. Roszak (red.), Camino de Santiago - nie tylko droga. Historia i wspótczesność Szlaku św. Jakuba w Polsce, Toruń $2012^{2}$, s. 87-102; por. także I. Gómez, Nota en torno a los “Orígenes del culto de Santiago en España, „Hispania Sacra” 7 (1954), s. 487-490. 
wało i prowokowało do ciągłego pokonywania „tego, co dalej”; do przekraczania granic, by nie zatrzymać się na tym, co zastane; by stawać się sobą przez „przekraczanie siebie” i otaczającego świata ${ }^{7}$.

Odkrycia dokonane przez Krzysztofa Kolumba zmusiły do naturalnej rewizji z dumą wypisanego hasła. Okazało się bowiem, że dalej jednak coś jest! Plus ultra! To właśnie te słowa stały się częścią rodowego herbu dynastii Burbonów, która do dziś panuje w tym kraju. To niejako wspólny mianownik tego, co dziś określamy duchem hiszpańskości ${ }^{8}$. Wspomniana graniczność (,nowego” i „starego” świata, muzułmańsko-chrześcijańska, europejsko-afrykańska, skoro - jak mawiał Aleksander Dumas - „Afryka zaczyna się za Pirenejami”) w kontekście historii Hiszpanii nie dotyczy jednak jedynie aspektu geograficznego, lecz wyznacza pewne prawidło historii, w którym mieszkańcom Iberii przyszło opowiedzieć się po jednej lub drugiej stronie, zajmować stanowisko wobec rodzących się nowych kultur i systemów. Znaczna część historii Hiszpanii upływa pod znakiem rekonkwisty i przesuwania granic, co doprowadziło do ukształtowania przekonania o odpowiedzialności za własną tożsamość oraz kierowało ku projekcji na Nowy Świat ${ }^{9}$.

Wydarzenia z epoki mozarabskiej nauczyły jednak mieszkańców Iberii umiejętności życia nie tylko w jednorodnym układzie społecznym, ale i w mniejszości (społecznej, religijnej, kulturowej) jako ocalała reszta z dawnej epoki i kultury (np. wizygockiej). A właśnie owa świadomość bycia „resztą” - co dobitnie pokazuje również przykład Izraela w Starym Testamencie - wiąże się z pielęgnacją „kultury pamięci”, która zadawała pytania o źródłowość własnej kultury, jej siłę i rozwój ${ }^{10}$. Podobnie jak biblijna kategoria wybrania, która nie pokazuje jednego jako lepszego od drugiego (skoro został wybrany), lecz wymaga od wybranego ocalenia pewnego obszaru wartości, wyj-

\footnotetext{
Por. A. Gesché, Przeznaczenie, przeł. A. Kuryś, Poznań 2006, s.10.

8 Por. H. Raley, The spirit of Spain, Houston 2001.

9 L. Peñarroja, Cristianos bajo el Islam: los mozárabes hasta la reconquista de Valencia, Madrid 1993.

10 Szerzej na ten temat pisałem w: Mozarabowie - niespokojna mniejszość. Liturgia mozarabska jako projekt duchowości czasów „bycia w mniejszości” w kontekście „Brewiarza Gotyckiego”, „Teologia i Człowiek" 13 (2009), s. 79-98.
} 
ścia ku światu z pewnym przypomnieniem ${ }^{11}$. A zatem o czym mogą przypomnieć mozarabowie w dobie wielokulturowości?

\section{Mozarabowie i mentalność „reszty”: nieugiętej i twórczej}

Zanim przedstawimy temat znaczenia i wkładu mozarabów w refleksje nad multikulturalizmem, najpierw trzeba się zastanowić nad tym, kim byli mozarabowie i skąd pochodzi takie określenie? Rdzenna ludność dawnego królestwa Wizygotów, które upadło wraz z podbojem arabskim rozpoczętym przekroczeniem przez wojska Tarika Cieśniny Gibraltarskiej w 711 roku, nie podjęła decyzji o ucieczce przed zbliżającym się wrogiem, lecz postanowiła pozostać ${ }^{12}$. Oznaczało to konieczność poddania się procesowi arabizacji w niemal wszystkich obszarach życia społecznego, z wyjątkiem życia religijnego (za cenę dużego trybutu,jarach i chizia, które gwarantowały swoiste minimum wolności), choć i ono nie do końca mogło przebiegać zgodnie ze swoim naturalnym rytmem (zakaz używania dzwonów, ruina wielu kościołów, wyróżnianie chrześcijan czarnym kolorem ubioru etc.). Nie był to więc czas wolny od napięć. Zwłaszcza trzy pierwsze wieki noszą na sobie ślady silnej konfrontacji, wywołanej decyzjami kalifów: w 788 roku Hixen I zabrania używania języka hiszpańsko-łacińskiego i wprowadza przymus stosowania języka arabskiego; nieco później (w 796 roku) al-Hakam I zaszczepia na terenie kalifatu działalność ortodoksyjnej islamskiej szkoły prawniczej malakí, która zaczyna wywierać duży wpływ na instytucje państwa i zabrania jakiegokolwiek odejścia od tradycyjnej religijności islamskiej ${ }^{13}$. Mozarabowie tracą ostatnie złudzenia co do możliwości pokojowego współżycia i wzniecają powstania w trzech najważniejszych miastach al-Andalus: Meridzie, Toledo i Kordobie ${ }^{14}$. Dochodzi do walk, które zapisują się w historii świadectwami męczeńskiej śmierci.

11 J. Ratzinger, Bóg i świat. Wiara i życie w dzisiejszych czasach. Z kardynałem Josephem Ratzingerem - Benedyktem XVI rozmawia Peter Seewald, przekł. G. Sowinski, Kraków 2005, s. 195.

12 F. J. Simonet, Historia de los mozárabes de España, Madrid 1983.

13 Por. P. Guichard, Al-Andalus: 711-1492, Paris 2000, s. 54.

14 J. F. Rivera, Formas de convivencia y heterodoxias en el primer siglo mozárabe, [w:] Congreso Internacional de Estudios Mozárabes, Historia mozarabe, Toledo 1975, s. 3-16. 
Z biegiem czasu zostają określeni przez chrześcijan pochodzących z północnych królestw i księstw hiszpańskich (stawiających opór konkwiście arabskiej ${ }^{15}$ ) terminem „mozarabowie”, pochodzącym z języka arabskiego od musta'rib albo musta'rab, które wywodzą się od rdzenia czasownikowego 'araba, oznaczającego w sensie czynnym „kogoś czyniącego się podobnym do Arabów”, albo w sensie biernym „kogoś, kto przyjął zwyczaje arabskie”. Zatem człowieka określanego tym mianem cechowało zewnętrzne „arabizowanie” swojego dotychczasowego życia i zwyczajów, co czyniło go trudno odróżnialnym od innych, ale jednak odmiennym ${ }^{16}$. Tę odmienność - czytelną dla kultury arabskiej - mozarabowie utrzymali praktycznie przez cały okres rekonkwisty (symbolicznym jej końcem jest zdobycie Granady w 1492 roku, choć punktem przełomowym było już zajęcie Toledo w 1085 roku przez Alfonsa VI z Kastylii), a przejawiała się ona szczególnie na polu liturgicznym ${ }^{17}$. Pomimo postępującego w Hiszpanii procesu romanizacji liturgii realizowanego przez ruch cluniacki mozarabowie otrzymali jednak przywilej sprawowania liturgii w swoim rycie, który w ten sposób przeniósł w nowe czasy dziedzictwo pierwszych świętych Kościoła hiszpańskiego, autorów większości tekstów euchologicznych tej tradycji liturgicznej $^{18}$. Wielokulturowość, która de facto rodzi się na fundamencie troski o niezamazywanie swej tożsamości, przy oporze wobec większościowej opcji uniformizującej i wchłaniającej w dominujące struktury, okazuje się opatrznościowa również w tym wymiarze zachowania prastarych tradycji, które - gdyby nie postawa mozarabów - zostałyby bezpowrotnie stracone.

Bez wątpienia mozarabowie, choć początkowo stanowili większość, to jednak z biegiem czasu, dzięki łatwiejszemu credo islamskiemu oraz przywilejom podatkowym, stali się socjologiczną mniejszością w kalifacie. Trzeba pamiętać, że przewyższali kulturowo i cywilizacyjnie agresorów z Afryki, co sprawiło, że przez blisko 200 lat mogli prowadzić w miarę swobodną koegzystencję. Ocaliła ich kultura, która dała siłę zachowania swej tożsamości. Żyli z jednej

15 Pierwszy ślad tego sposobu określania chrześcijan z południa półwyspu, znajdujących się pod polityczną dominacją kalifów, spotykamy w aktach króla Alfonsa I.

16 P. Corominas, Dicionario crítico etimológico de la lengua castellana, Berne 1954, s. 244 b.

17 D. Urvoy, La pensée religieuse des Mozarabes face à l'Islam, „Traditio” 39 (1983), s. 419-432.

18 J. P. Rubio, Introduccion del rito romano y reforma de la Iglesia hispana en el siglo XI: De Sancho III el Mayor a Alfonso VI, [w:] J. M. Magaz, N. Alvarez, La reforma gregoriana en España, Madrid 2011, s. 55-76. 
strony w stałym napięciu związanym z oczekiwaniem na wyzwolenie, które, jak liczyli, miało przyjść ze strony chrześcijańskich królestw północy, a z drugiej - pod presją konieczności poddawania się zewnętrznej arabizacji ${ }^{19}$. Nie byli przy tym całkowicie jednorodną grupą społeczną: wśród nich ścierały się ze sobą dwie zasadnicze opcje: izolacjonistyczna, negująca jakikolwiek kontakt z kulturą arabską, idąca na wyniszczającą konfrontację (relatywnie niewielka), oraz większość ciesząca się z „oazy wolności” pomimo życia pod jarzmem $^{20}$. Choć status chrześcijan w państwach muzułmańskich był określany przez pryzmat bycia „ludźmi Księgi”, nie zmienia to jednak faktu, że mozarabowie pozostawali dla swoich nowych sąsiadów „dziwni”21.

Była to bowiem „istotowa «dziwność»”, która wiązała się z oporem wobec uniformizacji i pragnieniem ocalenia własnej tożsamości w wymiarze aksjologicznym. Ową memoria identitatis pielęgnowali dzięki mentalności „reszty”. Warto zatrzymać się przy tym inspirującym sformułowaniu, które ma korzenie biblijne, sięgające tradycji prorockich Starego Testamentu i zapowiedzi powrotu „Reszty Izraela” z niewoli babilońskiej. W przypadku mozarabskim wyraża świadomość imperatywu, aby nie dać się zdominować za cenę przywilejów i przyzwyczajeń, ale podjąć się ambitnego programu ochrony i odbudowy fundamentów w niesprzyjających okolicznościach historycznych i społecznych. Ta dalekosiężność myślenia wymagała od mozarabów kroczenia śladami przeszłości, własnej historii, a przy tym otwartości, która nie będzie zdradą;jak również przekonania, że znajdują się na froncie walki o wartości i tożsamość, gdzie każdy ma swoje zadanie i każdy z nich się liczy. Takie dobitne przekazy pozostawili po sobie mozarabscy męczennicy z VIII i IX wieku, już w pierwszym okresie dominacji islamskiej, z ich odważnym i cennym non possumus, odbieranym przez wielu jako prowokowanie nowych panów Iberii ${ }^{22}$.

19 Por. M. A. Makki, El islam frente a las minorias cristianas, [w:] Actas de la I Jornada de Cultura Islamica „Al-Andalus, ocho siglos de la historia”, Toledo 23-26 de abril de 1987, Madrid 1989, s. 43-50.

20 M. López Gómez, The Mozarabs: worthy bearers of Islamic culture, [w:] S. K, Jayyusi, The legacy of Muslim Spain, Leiden 1992, s. 171-175.

${ }_{21}$ Por. F. Corriente, El léxico árabe andalusi según P. De Alcalá, Madrid 1988, s. 134; Y. BealeRivaya, The history and evolution of the term ,mozarab", ,Imago Temporis. Medium Aevum" 4 (2010), s. $51-71$.

${ }^{22}$ Jednym z najsłynniejszych męczenników był Perfectus († 850) - por. E. L. Gutierez, Los Mártires de Córdoba y la Política anticristiana contemporanea en Oriente, „Revista de Estudios Árabes” 15 (1994), s. 453-462. 
Ich postępowanie, które znalazło odbicie w architekturze, sztuce (piśmiennictwie) i liturgii - bo w tych obszarach pozostawili swoje materialne ślady - nie przypominało obrony twierdzy przed wrogami, zamykania się niczym w Wieczerniku sprzed zesłania Ducha Świętego czy izolowania, lecz umiejętność, możliwą do opisania jako pewna ars (Tomasz z Akwinu, idąc za tradycją augustyńską, będzie nawet mówił o Chrystusie jako ars Patris! ${ }^{23}$ ), bycia zaczynem, który przygotuje nowy rozkwit własnej kultury. Dlatego mozarabską receptą na życie (o czym świadczy właśnie teologia rytu hiszpańsko-mozarabskiego) była przejrzystość, widoczność najważniejszych wartości. Być może dla wielu był to pewien heroizm wierności „za wszelką cenę", ale to on nie pozwolił zaschnąć źródłom tożsamości, otwierając na odkrycie prawdziwego sensu' ${ }^{24}$.

Mozarabowie stali się resztą walczącą (dziś niestety również zapomnianą), niepogodzoną z niesprawiedliwą sytuacją dominacji, lecz chcącą brać udział we „współrzędnych kulturowych”, na których pisała się codzienność. Mieli jasną świadomość kulturowej granicy, która określała ich tożsamość pielęgnowaną przez wiarę chrześcijańską, język i ryt liturgiczny ${ }^{25}$. Na co dzień dwujęzyczni, ubogacili łacinę licznymi arabizmami i byli tymi, którzy dzięki pracy w skryptoriach przekazali kulturze zachodniej wiele dzieł arabskich uczonych z zakresu medycyny, astronomii i filozofii (słynna szkoła tłumaczy z Toledo, zwłaszcza działalność Jana z Sewilli, pracującego pod opieką biskupa Rajmunda) ${ }^{26}$. Ich asymilacja na odzyskanych terenach Hiszpanii była wolna i pełna napięć - paradoksalnie ostatnią bitwą, którą musieli stoczyć, była obrona własnej liturgii ${ }^{27}$.

Walka o tożsamość toczyła się jednak nie tylko wobec muzułmańskich najeźdźców, ale także wśród samych chrześcijan, koncentrując się wokół skomplikowanych sporów chrystologicznych, które nieprzypadkowo pojawiły się

23 Por. Scriptum super libros Sententiarum, lib. II, d. 13, q. 1, a. 5, s.c. 2.

24 Por. K. Śnieżyński, Pamięć w myśleniu religijnym. Kultura wspominania, zapominania i nadziei, „Analecta Cracoviensia” 42 (2010), s. 87-112.

25 M. López Gómez, The Mozarabs: worthy bearers of Islamic culture, dz. cyt., s. 171-175.

26 M. A. Gallego, The languages of medieval Iberia and their religious dimension, „Medieval Encounters" 1 (2003), s. 107-139.

27 Por. R. Barkai, Cristianos y musulmanes en España medieval (El enemigo en el espejo), Madrid 1984. 
Hiszpanii w tym właśnie momencie. Jest czymś niezwykłym, że w tak trudnej życiowo sytuacji chrześcijan utworzyło się silne stronnictwo teologiczne opowiadające się za starożytną koncepcją adopcjanizmu, czyli poglądem odrzucającym prawdziwe bóstwo Chrystusa, jedyność Jego osoby, i przyjmujące, że jest adoptowanym Synem Bożym. Jest jedynie wybitnym człowiekiem, który za swoje dobre, przykładne i pełne zaufania Bogu życie został przez Stwórcę wywyższony. Nie jest to opinia nowa, lecz będąca echem poglądów ariańskich i prenestoriańskich. Musi jednak budzić zdziwienie niezwykły paralelizm z poglądami muzułmańskimi na temat Jezusa, którego wyznawcy islamu postrzegają jako jednego z proroków ${ }^{28}$. Czy była to próba „złagodzenia” wierności mozarabów prawowiernemu nauczaniu Kościoła i w ten sposób powolnego „łamania” i poddawania arabizacji?

Przy całej trudnej sytuacji, w jakiej znaleźli się mozarabowie - zwłaszcza w obliczu kolaboracji niektórych środowisk, które czuły się prześladowane za czasów Wizygotów - bronili oni tożsamości swej wiary, widząc właśnie w chrystologii punkt ciężkości. Wskazują na to szereg liturgicznych idei (zwłaszcza powszechna pobożność pasyjna czcząca Chrystusa jako współcierpiącego z wiernymi, w tym przypadku z mozarabami), układ architektoniczny świątyń (labirynty i ciemności, swego rodzaju ukrycie) oraz szczególne upodobanie w komentowaniu jednej z ksiąg liturgicznych: Apokalipsy św. Jana.

Wszystkie te okoliczności stanowią składowe ich skomplikowanej sytuacji życiowej. Wielu współczesnych myślicieli zwraca uwagę na szczególne znaczenie świadomości doświadczanego cierpienia-memoria passionis ${ }^{29}$. Bez wątpienia znajduje ona swój wyraz również w liturgii hiszpańsko-mozarabskiej, która przecież często odnosi się z czcią do świadectwa męczenników, czyli niezłomnych świadków własnej tożsamości. Mozarabska liturgia pozostaje w źródłowym cieniu tych świadków i ich drogi, stając się rytem męczenników, którzy nie zdezerterowali, lecz okazali się wierni.

28 Wedle wyjaśnień, najprawdopodobniej idee adopcjanistyczne (które rzucą cień podejrzenia na całą liturgię hiszpańską, niesłusznie zresztą, jak wykazały liczne badania zlecane przez papiestwo w ciągu wieków) przynieśli ze sobą nestorianie, którzy wygnani z imperium bizantyjskiego znaleźli schronienie wśród Arabów i z nimi przybyli do Hiszpanii.

${ }_{29}$ J. B. Metz, Memoria passionis. Una evocación provocadora en una sociedad pluralista, Santander 2007, s. 61. 


\section{Liturgia hiszpańsko-mozarabska: paradygmat troski o tożsamość}

Liturgia nie jest wyizolowanym aktem życia człowieka, zredukowanym do intelektualno-duchowego przekazu pewnych treści, lecz obejmuje całego człowieka, w jego tu i teraz, duchowości i cielesności, a nade wszystko jego historii; zaproszonego do uczestnictwa w rzeczywistości, która go przekracza. Liturgia zatem przeprowadza go przez „próg transcendencji oraz zrozumiałości"30 i posiłkuje się językiem, który w obliczu nieogarnioności istoty Bożej nie chce milczeć, lecz wręcz przeciwnie, odpowiedzieć na zaproszenie Stwórcy z perspektywy własnej, konkretnej sytuacji życiowej. Dlatego liturgia nie jest zbiorem form, które pochodzą z życia społecznego, lecz jest zupełnie odwrotnie: to ona nadaje kształt każdej chwili historycznej, staje się wskazówką, jak przekształcać świat. Uczy odrzucania idolów i fałszywych wzorów. Ta paradygmatyczność liturgii odżywa we współczesnej refleksji filozoficznej, która czerpie natchnienie z opisu i doświadczenia liturgicznego, czego wybitnym przykładem jest anglosaski ruch radykalnej ortodoksji, skupiający takich myślicieli, jak John Milbank, Catherine Pickstock czy Graham Ward ${ }^{31}$.

Wydawałoby się, że sytuacja, w której znaleźli się mozarabowie w nowych realiach społeczno-politycznych Iberii, sprawi, że najwygodniejszym rozwiązaniem będzie pewna forma „etyki akomodacyjnej”, którą i dziś niektórzy wskazują jako jedyną receptę na multikulturalizm. Wedle tej koncepcji należy zminimalizować potencjalne konflikty z tymi, z którymi graniczymy, a z którymi nie podzielamy opinii na temat moralności. Kazus mozarabski jasno pokazuje, że to nie wystarczy dla integralnego rozwoju społecznego, gdyż musi pojawić się coś więcej niż zwykła koegzystencja - potrzebna jest pewna harmonia wartości. Są takie pluralizmy, które nie prowadzą do relatywizmu ani nie implikują nihilizmu, a przez to wartości nie tracą na swojej obiektywności, ale są też takie, które sta-

$30 \quad$ P. Gesché, Przeznaczenie, dz. cyt., s. 75.

31 Przypominając, jak wiele zawdzięcza tożsamość europejska średniowiecznemu konstytualizmowi, który z kolei był aplikacją eklezjologicznej idei „Ciała Chrystusa” - por. J. Milbank, Multiculturalismo en Gren Bretaña: el caso del reciente debate sobre la sharia, [w:] J. Prades, M. Oriol, Los retos del multiculturalismo. En el origen de la diversidad, Madrid 2009, s. 265. 
ją się ukrytym totalitaryzmem, czego zdaje się doświadczyli mozarabowie w tamtym czasie ${ }^{32}$.

Z tego właśnie powodu ryt hiszpański jawi się jako interesujący przedmiot studium nie tylko historycznego, ale teologicznego. Liturgia hiszpańsko-mozarabska jest utkana z tekstów, które nosząc znamię wrażliwości poetyckiej ojców Kościoła pochodzących z Hiszpanii. Zostały one na nowo odczytane po inwazji w 711 roku i stały się tym, co kryje w sobie termin „kultura”. Można właściwie powiedzieć, że w tym przypadku „wiara stała się kulturą"

\subsection{Historia liturgii hiszpańskiej}

Liturgia hiszpańsko-mozarabska sięga swymi korzeniami pierwszych wieków chrześcijaństwa, które do Hiszpanii dotarło najprawdopodobniej z Afryki, o czym mogą świadczyć częste korespondencje biskupów i pisarzy kościelnych ze wspólnotami kościelnymi na tym kontynencie oraz powszechny kult św. Cypriana z Kartaginy we wszystkich niemal rejonach Półwyspu Iberyjskiego ${ }^{34}$. Ryt hiszpańsko-mozarabski rozwijał się w trzech głównych (najpierwszych) centrach rzymskiej, a potem wizygockiej Hiszpanii: Toledo, Sewilli i Tarragonie, odpowiadającym stolicom dawnych prowincji Imperium Romanum. Nas jednak interesuje chwila, w której liturgia sprawowana w cesarstwie rzymskim, później królestwie Wizygotów, stała się liturgią mozarabów: chrześcijan, którzy pozostali pod władzą muzułmanów ${ }^{35}$. Zostaje w ten sposób niejako nasączona sytuacją konfrontacji i procesu arabskiej uniformizacji, której mozarabowie byli programowo poddawani, i dlatego w dyskretny sposób, kryjąc się niejako w cieniu znamiennych konceptów teologicznych, liturgia ta oddaje pełne napięć wydarzenia. Nie tylko odzwierciedla

32 Na filozoficzne tło debat o pluralizmie kultur i jego konsekwencji wskazuje ciekawa praca zbiorowa, podejmująca szereg wątków etycznych, społecznych i politycznych - por. L. Foster, P. Herzog, Defending diversity: contemporary philosophical perspectives on pluralism and multiculturalism, Amherst 1994.

33 Por. I. Saranyana, Cuando la fe se hace cultura, „La Vanguardia” z dn. 19.02.2012.

34 J. Pinell, Hispánica (liturgia), [w:] Diccionario Patrístico y de la Antiguedad Cristiana, ed. A. Di Bernardino, vol. II, Salamanca 1998², s. 1048-1054.

35 J. Pinell, J. Pons, La estructura de la misa en rito hispánico, herencia de la tradición universal y de su propia historia, „Notitiae” 267 (1988), s. 471-727. 
trudności, z którymi musieli się zmierzyć na co dzień, ale sugeruje pewien istotny, chrześcijański modus vivendi na trudne czasy.

W tej perspektywie możemy lepiej zrozumieć, dlaczego życie pod jarzmem (sub iugo) to jeden z częstych motywów, który możemy spotkać, analizując formularze z Mszału Hiszpańsko-Mozarabskiego [dalej: MHM]. Opisują one sytuację uciemiężenia, w której znajduje się człowiek przede wszystkim przez własny grzech, ale trudno nie odkryć we frazach takich jak durissimum et sensuale iugum odniesienia do twardego i fizycznego, dotykającego niemal wszystkich zmysłów prześladowania, doświadczanego na co dzień ze względu na chrześcijańską tożsamość ${ }^{36}$. Zwłaszcza że iugum pojawia się MHM w kontekście brzemienia prawa (iugum legis), które Chrystus przyszedł z nas znieść, i często w tekstach z mszy o świętych męczennikach.

Dla tak przeżywających liturgię wolność wiąże się z pieczołowitą troską, aby nie dać jej sobie wydrzeć za cenę drobnych korzyści, co być może jest echem przechodzenia na islam części mozarabów w zamian za zwolnienie z podatków: quia melius est libertatem quaerere, quam per confidentiam non habere ${ }^{37}$. Pewnie dlatego w pełnej „paschalnego dynamizmu” poezji teksty euchologiczne liturgii mozarabskiej posługują się porównaniem wytrwania w wierze do podróży morskiej: w tej doczesnej navigatio ważne jest, aby dobrze rozpoznać dobro i niegodziwość, nazwać je po imieniu, nie dać się zwieść łatwej pewności i taniej wierze, które mogą doprowadzić do katastrofy, osłabiając czujność żeglarzy. Trzeba nauczyć się omijania tego, co zbędne, aby nie rozbić swego życia, lecz dotrzeć do tego, co wartościowe i nieprzemijające ${ }^{38}$. Bez wątpienia mozarabowie byli doświadczonymi sternikami po morzu dominacji islamskiej, którzy nigdy nie ustawali w modlitwie, prosząc o pokój dla Kościoła, aby Pan zmiłował się nad nimi i oddalił od nich niebezpiecznych przeciwników (repulsis adversariis).

36 Określenie pochodzi z mszy przewidzianej na dzień św. Klemensa - 23 listopada w kalendarzu mozarabskim (In diem sancti Clementi): „ut qui veram pacem pacifici praedicando durissimum et sensuale a diversis nationibus sufferumus iugum, per te que vera et firmissima pax es, pervenire mereamur ad paradisi gaudium sempiternum".

${ }_{37}$ In $V$ feria Paschae, alia.

38 In $V$ feria Paschae, alia: „Ad aeternam nobis vitam, quasi quiddam pelagus, data es temporis navigatio, ut inter bonorum et iniquitatis excursum, aut peccatum pereat, aut peccator, ut aut excurrat fides circumspecta navigium, aut incurrat securitas incauta naufragium". 
Jeszcze bardziej wyraźnie widać to napięcie w wyjątkowym i oryginalnym w liturgii mozarabskiej formularzu mszy Pro tribulatis, a więc za prześladowanych, zmagających się z losem, cierpiących. Nie chodzi jedynie o tych, którzy doświadczają trudności życiowych (jak np. choroba), lecz stawiających czoło przeciwnościom (diabolica et humana adversitas) ze świadomością, że gra toczy się o wysoką stawkę. Dzięki odpowiednio dobranym łacińskim terminom teksty euchologiczne przywołują obraz oblężenia, do którego doprowadzają kumulujące się przeciwności, podstępne knowania, oskarżenia. Nie pozostaje nic innego jak uciekać się do Pana, prosząc, aby rządził przez swe miłosierdzie i nie dopuszczał do wyczerpującego Jego wiernych biczowania przez przeciwności czy „dokuczliwego szemrania”, lecz wyposażył ich w „broń sprawiedliwości”. Ona - sprawiedliwość - dziwnie ulega zatarciu w takich sytuacjach. Dlatego liturgiczne misterium kończy modlitwa zwana completuria, która staje się okrzykiem nadziei, że naciski i presja doświadczana w teraźniejszości zaowocuje duchowym bogactwem, które odkłada się dla nich dzięki cierpliwości i wytrwałości w obronie tego, co najistotniejsze.

\subsection{Ars identitatis a liturgia mozarabska}

By zrozumieć wyjątkowość doświadczenia mozarabskiego, trzeba spojrzeć na nie z szerszej perspektywy czasu, podobnie jak jest z badanym przedmiotem, do którego trzeba zachować pewien dystans, oddalić od oczu. Pod koniec XIX wieku słowa „kultura” zaczyna się częściej niż dotychczas używać w liczbie mnogiej, co staje się jasnym przejawem zerwania z pewnym ideałem oświeceniowym (a jest to konsekwencja zarówno heglizmu w wymiarze horyzontalnym, jak i teorii Schillera i Nietzschego w sensie wertykalnym) ${ }^{39}$. Kluczem jednak do zrozumienia tego zjawiska jest rozszyfrowanie relacji między „tożsamością” a „różnicą”, które wydają się wzajemnie wykluczać i stają się zarzewiem konfliktów. Jedną z prób jej odczytania jest tzw. „pluralizm analogiczny" (Mauricio Beuchot), który operując klasycznym pojęciem analogii, chce - w duchu fronesis - ocalić różnice kulturowe bez niszczenia

39 J. Alejandro, Pluralismo cultural desde dos versiones: espistemológica (León Olivé) y 'hermenéutico-analógica' (Mauricio Beuchot), [w:] Hermenéutica, analogía y diálogo intercultural, cord. A. Carrillo, Publa 1999, s. 56. 
wartości uniwersalnych. W każdym razie tożsamość i różnica w paradygmatyczny sposób opisują anatomię wielokulturowości w każdej z epok. Z podobną sytuacją mamy do czynienia w przypadku mozarabów, którzy stają na straży własnej tożsamości. Bronią jej i jednocześnie tworzą.

Ich modus operandi opiera się na świadomości normatywnego wymiaru pamięci zbiorowej, ale także wszelkiej pamięci, również kulturowej i religijnej. W przypadku tej ostatniej - „pamięci religijnej” - współtworzy ją swoista „linia wierzących” w ciągu wieków, która przekracza samą historię, będąc zakorzenioną i zmierzającą ku wieczności. Manifestuje się w akcie istotowo religijnym, którym jest anamnesis przeszłości, nadająca sens teraźniejszości i ukierunkowująca przyszłość. Przyjmuje najczęściej postać rytu, którego wyróżnikiem od innych fenomenów społecznych będzie znamienna powtarzalność gestów. Ma ona wpisać w ciąg czasu pamięć o wydarzeniach fundacyjnych, które ukonstytuowały ową „linię”. U źródeł więc pamięci i tożsamości drzemie przekonanie, że musi istnieć pewne continuum, choćby minimalne, historii jako takiej.

Tę sztukę tożsamości rozumianej jako troska o ocalenie continuum mozarabowie uprawiają w zakresie tego, co specyficznie chrześcijańskie, mianowicie lektury Pisma Świętego w czasie celebracji liturgicznej, skupiając swą uwagę, co niezwykle znamienne, na księdze Apokalipsy. Odkrywają w tej księdze ważne przesłanie dla samego siebie. Wielkim skarbem tradycji mozarabskiej są ko m entarze do A pokali psy, tzw. Beato (od imienia mnicha z Kantabrii, odznaczającego się wybitną wiedzą i kulturą religijną, który pod koniec VIII wieku zaczął pisać komentarze do Apokalipsy), znane z licznych miniatur unaoczniających intelektualny świat tych ludzi. Pojawiają się w IX wieku, a rozkwit przeżywają w wieku X w królestwach chrześcijańskich na północy półwyspu. Sama sztuka miniaturystyczna jest już znakiem integracji wielu sprzecznych form. Eklektyzm mozarabski nie był zwykłym zestawianiem obok siebie, lecz aktem twórczym, który nosił osobiste piętno autorów, nie do pomylenia $z$ innymi ${ }^{40}$. Wspomniane komentarze miały szczególny wydźwięk, gdyż przedstawiały sytuację chrześcijan

${ }^{40}$ Najbardziej znani wśród miniaturzystów są Magio i jego uczeń Emeterio, twórcy szkoły w Tabara, ale także Florencjusz i Vigila. 
z kalifatu w perspektywie starć opisywanych przez Apokalipsę, często eksponującą zło siane przez Antychrysta.

Świadectwem i nośnikiem tożsamości była także a rchitektura mozarabów, która odzwierciedlała ich sytuację i relację ze światem zewnętrznym. Świątynie budowano na planie krzyża, a poszczególne elementy bryły kościoła różniły się wysokością, dając wrażenie zbioru figur, przez co stawały się swoistym labiryntem, z którego wyjście zna tylko Chrystus. W budowlach niemających wiele światła, pełnych półmroku nie można było praktycznie ocenić realnych kształtów, co miało wyrażać nadzieję na Prawdziwe Światło (Lux vera), które przyniesie pokój. Dlatego świątynie mozarabskie cechuje przełamanie linii horyzontalnej rzędem kolumn, małych brył, ikonostasem, rozbijającymi jakiekolwiek continuum. Takie wrażenie ma dziś każdy, kto znajdzie się we wnętrzu Mezquity w Kordobie ${ }^{41}$. Zatem świątynie te intuicyjnie wyrażają w liturgii świadomość, że gra toczy się o przełamanie ich historycznego, religijnego continuum, krótko mówiąc wykorzenienie, i dlatego w rycie odnajdują siłę i pomoc, aby stawić temu opór.

Dyskretne drzwi do świątyń mozarabskich nie przypominają prawdy o przejściu w świat sacrum, raczej zachęcają do przyjścia do świątyni w południe, gdy jest największy skwar ${ }^{42}$. Dlatego mozarabowie upatrywali w liturgii formy odzyskiwania duchowej mocy, która nie tylko pokrzepiała, ale pozwalała kontynuować wysiłek podjęty dla słusznej sprawy.

${ }^{41}$ Wszystko to jednak uzmysławia istnienie praktycznie istotowego modelu relacji islamsko-chrześcijańskich na terenie Półwyspu Iberyjskiego jako con-vivencia, która nie skończyła się wraz ze zdobyciem Granady (1492), lecz naznacza praktycznie całą historię Hiszpanii, w której muzułmanie i ich kultura funkcjonowali jeszcze bardzo długo. Być może to doświadczenie przenikania się kultur sprawiło, że Aleksander Dumas (ojciec) uważał, że „Afryka zaczyna się za Pirenejami" - por. B. A. Catlos. The victors and the vanquished: Christians and Muslims of Catalonia and Aragon, 1050-1300, Cambridge 2004; o konsekwencjach tej obecności kultury muzułmańskiej dla zrozumienia fenomenów współczesnej Hiszpanii traktuje B. Fuchs, Exotic nation: maurophilia and the construction of early modern Spain, Philadelphia 2009, s. 13.

${ }_{42}$ Spośród innych cech architektonicznych zwraca uwagę fakt, że kolumny nie nawiązują do arabskich z Kordoby, a bardziej do preromańskich. Dominuje ornamentyka roślinna lub skupiona na figurach. Ale tym, co właściwe „mozarabom”, jest tzw. alfiz, ozdoba architektoniczna, swoista rama, która otacza łuk. 


\subsection{Liturgiczna „intersubiektywność”}

Musi więc zastanawiać, co takiego spotkali mozarabowie w swej tradycyjnej liturgii, co pomogło mi ocalić tożsamość. Nie była to jedynie historyczna nostalgia za odległymi czasami, które zapisały się w pamięci zbiorowej jako czas świetności ${ }^{43}$. To coś więcej - świadomość dokonującego się między uczestnikami (zarówno w wymiarze horyzontalnym, jak i wertykalnym) faktu, który teologia oddaje niezwykle ważnym terminem commercium (wymiana). Zazwyczaj jest on stosowany w chrystologii (z dookreśleniem admirabile) na określenie przyjęcia człowieczeństwa przez Słowo, ale także w drugim kroku jako nasze uczestnictwo w Bożej naturze Słowa. Niemniej jednak również liturgia jest doświadczeniem tej wymiany, która rodzi się na bazie kultycznego spotkania, z którego człowiek już nie wychodzi taki sam. Dokonała się w nim zarówno wymiana łaski (negotio Christi, jak zauważy liturgia mozarabska), jak również duchowe ubogacenie wspólnym wychwalaniem Pana, które ma swoje uzasadnienie w intersubiektywności uczestniczących w liturgii.

Intersubiektywność w tradycji tomistycznej oznacza relację opartą na dialogu lub komunikacji. Wymaga posiadania „siebie”, minimalnej świadomości swojej tożsamości, owego „ja”, które ontologicznie wyprzedza „my” (np. w przyjaźni). Nowa przestrzeń jest budowana przez dopełniające się działanie dwóch osób. Relacja bowiem rośnie wykładniczo, otwierając się ciągle na nowe relacje. Wymaga to jednak zasadniczej cechy, aby uczynić siebie widzialnym dla innych. Trochę jak w wodzie, którą stanowią H i O, odrębne, a razem tworzące coś więcej niż dwa pierwiastki. W myśli tomistycznej intersubiektywność nie może istnieć bez substancjalnej tożsamości dwóch podmiotów.

Podkreśla to esse in medio, „bycie pośrodku”, odnoszone nie jedynie do teorii cnoty jako znajdującej się pośrodku dwóch skrajności, ale w kontekście liturgii oznaczające specyficzną prawdę o charakterze kultu Bożego jako sprawowanego „pośrodku Kościoła”. Chodzi o prawo do widzialności, zauważa św. Tomasz, obecności w przestrzeni publicznej, w której głos praw-

${ }^{43}$ Por. S. R. Doubleday, D. Coleman, In the light of medieval Spain: Islam, the West, and the relevance of the past, New York 2008. 
dy staje się słyszalny, ale także wskazuje się na intymność, głębokie przylgnięcie właściwe doskonałym. Liturgiczne spotkanie w wielości członków Mistycznego Ciała Chrystusa dokonuje się pośrodku Kościoła właśnie ze względu na głębokie przylgnięcie do swej chrześcijańskiej godności, a przy tym stabilitas contra mala, et firmitas ad bona ${ }^{44}$.

\section{Hiszpania - „zderzak” Europy}

Z przedstawionej powyżej perspektywy historycznej łatwiej można dostrzec i ocenić dokonujące się na naszych oczach przemiany świata. Trudno ignorować nową konfigurację społeczeństw wielokulturowych, zwłaszcza w kontekście pewnej wewnętrznej „fragmentaryzacji” na mniejsze kultury, a w konsekwencji oddzielenia mniejszości, relatywizmu kulturowego etc., których doświadczyła Europa zwłaszcza w ostatnim wieku (proces sekularyzacyjny odegrał tu istotną rolę); kultury te z kolei - walcząc z wcześniej dominującymi, zaczęły szukać sprzymierzeńca w kulturach przychodzących z zewnątrz.

W obliczu tej sytuacji można dostrzec współcześnie dwa modele postępowania: z jednej strony to podkreślanie wartości każdej kultury broniącej pewnego ideału „społeczeństwa-mozaiki”, w którym jedna kultura znajduje się „obok” drugiej, ale bez dokonywania porównań aksjologicznych ${ }^{45}$. W jakiejś mierze utożsamia to propozycja klasycznego multikulturalizmu. W innym modelu nacisk zostaje położony na stworzenie pewnej wspólnej kultury, do której winny się dopasować te mniejszościowe, zwłaszcza w obszarze publicznym (asymilacjonizm). Za obydwoma rozwiązaniami stoją jednak istotne przesłanki filozoficzne, których nie wolno przeoczyć: to relatywizm pierwszego modelu i uniwersalizm oświeceniowy drugiego. W jakiejś mierze zostaje także naruszony etos prawdy i wolności: prawda zostaje przez multikulturalizm „poświęcona" na ołtarzu wolności.

$44 \quad$ In Psalmum 45, n. 4.

45 Por. J. M. García Gomez-Heras, Un paseo por el laberinto. Sobre política y religión en el diálogo entre civilizaciones, Madrid 2008, s. 20. 
Niemniej jednak niektórzy wolą mówić o ,interkulturalizmie”, ale przecież on też nie pragnie zagłębić się refleksyjnie nad istotą kultur, a jedynie doprowadzić do liberalnej koegzystencji. Od zawsze istnieje napięcie między uniwersalnością i partykularnością, one się wzajemnie przenikają. Ale uniwersalizm kultur to nie suma poszczególnych kultur, ale pewien ideał „pełni”, idealna harmonizacja prawd dających się zintegrować, a z drugiej historyczne owoce spotkania ze sobą różnorakich form ich istnienia: separacji (integracji) lub konfrontacji (starcia), które są rezultatem „dialektyki tradycji”, o której pisał Alasdair McIntyre. To spotkanie kultur umożliwiają wartości fundamentalne ${ }^{46}$.

Chodzi o więź ubogacającą, wolną od prób narzucania jednego drugim i dlatego domagającą się komunikacji kulturowej opartej na wartościach ${ }^{47}$. W ten sposób staje się propozycją aksjologiczną, wzmacniającą osoby i grupy społeczne, potęgującą interrelacje między różnymi kulturami, stwarzającą wspólną przestrzeń kulturową, bez rezygnowania z własnej tożsamości. Interkulturalizm, jak się dziś podkreśla, musi zostać na nowo przemyślany, powinna nastąpić swoista rekonceptualizacja, która nie ograniczy się do powierzchownej akceptacji „innej kultury” jedynie ze względu na jej „inność”, lecz dostrzeże stojącą za nią konkretną osoby, będącą podmiotem tejże kultury. Różnica między ujęciem multikulturalizmu a interkulturalizmu polega na integracji kulturowej i polityce różności. Chodzi o to, w jaki sposób traktuje się różnice, czy jesteśmy w stanie oprzeć je na bazie aksjologicznej, na relacji do prawa do tożsamości, wolności, godności, sprawiedliwości w obliczu zobowiązania państwa wobec swoich obywateli. Jest to możliwe dzięki etyce, która szanuje indywidualność jednostki i uniwersalność wartości, co powinno prowadzić do synergii, a nie konfrontacji.

Widoczne jest to w podejściu do wielokulturowości, którą zdominował aspekt poznawczy, rozumienia i szanowania idei, tradycji, języka, spychając na dalszy plan osobę za nią stojącą. Tymczasem właśnie to tło antropologiczne i moralne jest decydujące. Wielokulturowość nie może zatrzymać się

46 M. Fernandez del Riesgo, El papel del cristianismo en la configuración de la identidad europea ante el reto de la secularización y del multiculturalismo, „Ciencia Tomista” 3 (2011), s. 623.

${ }_{47}$ Więcej o konsekwencjach pedagogicznych wynikających z interkulturalizmu w artykule: J. M. Lopez, La educación intercultural como ejercicio de educación en valores, „Estudios Sobre Educación" 10 (2006), s. 9-36. 
na przyjęciu kultury drugiego, lecz musi prowadzić do przyjęcia jego osoby. Kody odmienności pociągają za sobą współzależność, solidarność, uznanie wartości dzięki świadomości, że tożsamość to coś więcej niż suma cech podmiotu, ale także sieć dynamicznych relacji, w które włączają się osoby i grupy. Relatywizm multi- czy plurikulturalizmu może doprowadzić do zamknięcia w inności, w pewnych ramach, aby w ten sposób zabezpieczyć własny stan posiadania i władzę. Dlatego wymaga się odpowiedzialności jako postawy fundamentalnej oraz partycypacji, która ożywia demokrację. Trzeba pokazać, że kultury należy orientować wokół wartości, bo przecież najważniejsze to odkryć, do jakiego portu chce się dopłynąć. Nie oznacza to utylitarystycznego traktowania kultury, ale pewną naturalną grawitację ku wartościom.

Obecnie szuka się punktu spotkania, w którym można by rozwinąć „autentyczne" współżycie kultur (nieideologiczne). Na mapie pojawia się wiele propozycji: se mantyka relacyjna (Pierpaolo Donati), szukająca kryterium komunikacji między kulturami, doświadczenie podstawowe (Carmine di Martino) czy prawa człowieka (Marta Cartabia) albo kategoria u z n a n i a (Francesco Boturri). Na tle tak zarysowanej panoramy warto pytać o jakość spotkania kultur, które nie polega na poszukiwaniu najmniejszego wspólnego mianownika, lecz zaprezentowaniu poprzez świadectwo własnej tożsamości otwartej na wszystkich (Javier Prades). Umożliwia to sama struktura kultury, która zakłada taką „,penetrację” tego, co uniwersalne, atemporalne, partykularne i historyczne.

\subsection{Nowe fenomeny: „nowa laickość” i „nowy ateizm”}

W analizie aktualnej sytuacji multikulturalizmu warto odwołać się do przemyśleń Remiego Brague’a, wskazującego na charakterystykę starożytnej postawy rzymskiej, która pojawia się jako owoc tego, co określa jako genius Europy: umiejętność „czuwania, otrzymywania i przekazywania”, a przy tym umożliwiająca ewoluowanie w kontakcie z tym, co nowe, co się otrzymało (a tym mówiąc, w dużym skrócie, były Ateny i Jerozolima). To rzymskie podejście do innych kultur zostało wzmocnione przez kontakt z chrześcijaństwem ${ }^{48}$. Mówiąc metaforycznie, bierzemy na plecy to, co otrzymaliśmy,

48 R. Brague, Il futuro dell'Occidente, Milan 1998, s. 118nn. 
aby spotkać się z naszym „dziś”. Jest to „reaktualizacja” doświadczenia konstytutywnego - na co ciekawie i inspirująco wskazuje mit Eneasza: doświadczenie tego, co stare, jako czegoś nowego, przeszczepionego na nową ziemię, czyniąc z tego, co stare - nową zasadę. Dlatego najgorszy w tym względzie jest „paraliż traditio”, zapomnienie o własnej tradycji i historii, który blokuje autentyczny dialog, bo odcina korzenie własnej tożsamości ${ }^{49}$.

W tym kontekście warto przyjrzeć się nowym fenomenom, które na nova mappa mundi pojawiają się z różnym natężeniem i w odmiennych zakątkach świata, ale multikulturalizm wydaje się swoistym tłem dla tych idei, owym środowiskiem, w którym mogą wzrastać. Na uwagę zasługują zwłaszcza dwa zjawiska, które naznaczyły najnowszą historię społeczną Hiszpanii: zyskujący na znaczeniu pomysł „nowej laickości” oraz przenikające do krwioobiegu społecznego idee tzw. „,nowego ateizmu”, docierające z Wielkiej Brytanii.

Pierwszy z przywołanych tematów - laickość z ważnym dopowiedzeniem „nowa” - poruszył umysły u progu XXI wieku. Nie miał być podobny do „starej laickości", agresywnej względem religii, nastawionej na konflikt (którego obrazem w wyobraźni zbiorowej społeczeństwa hiszpańskiego zawsze będzie wojna domowa 1936-1939), lecz utwierdzać w zbiorowej świadomości przekonanie, że religijność jest przejawem niedojrzałości intelektualnej oraz przeszkodą w pełnym korzystaniu z wolności. Wynika to w dużej mierze ze słabej formacji religijnej oraz błędnie ukształtowanej idei Boga i religii, ale ekspansja laicyzmu opiera się także na szeregu uproszczeń, a spośród nich na czoło wysuwa się postulat umniejszania roli religii w społeczeństwie wielokulturowym ze względu na jej możliwe ujście w fundamentalizmie, będącym źródłem przemocy ${ }^{50}$. Nie wszystkie rodzaje wielokulturowości zasługują na uznanie nowego państwa laickiego: jedynie ten multikulturalizm jest wartościowy dla państwa, który rodzi się jako konsekwencja odmienności pluralistycznej, natomiast odrzucany jest ten jego model, który byłby realizowany w imię odziedziczonych zasad religijnych czy rodzinnych.

49 A. Scola, Una nueva laicidad, Madrid 2007, s. 45-55.

50 Opis moralnych wyzwań stojących przed hiszpańskim chrześcijaństwem przedstawia ciekawy artykuł: J. Sánchez Cañizares, Non possumus. Refleksje o wspótczesnej sytuacji moralnej w Hiszpanii, [w:] Dysputy Nawarryjskie w Toruniu, red. P. Roszak, Toruń 2010, s. 25-40. W dużej mierze opieram się nad przedstawionych tam analizach, odczytując je jednak w kluczu interesującego nas zagadnienia multikulturalizmu. 
W praktyce oznacza to przyjęcie roli demiurga, który stwarza nową cywilizację praktycznie od podstaw, ustanawia nowy ład i nowe zasady, które nie respektują tradycji narodowych czy porządku moralnego. Właśnie dlatego sprawy religii będą systematycznie spychane w cień, na głębokie „dno sumienia”, aby zneutralizować jej siłę i ostatecznie usunąć z przestrzeni publicznej, tak aby nie przeszkadzała w „grze władzy” ziemskiej.

Laicyzm w nowym wydaniu kreuje rzekomy konflikt między wolnością i prawdą, właściwy filozofii relatywistycznej, opowiadając się za pierwszeństwem wolności. Ideologię laicką charakteryzuje koncepcja bytu ludzkiego, która w centrum stawia absolutne korzystanie z wolności, przez co Bóg powinien zniknąć, aby człowiek stał się wolny bez ograniczeń. Stoi za tym indywidualistyczna koncepcja wolności, która odczytuje społeczność jako coś przypadłościowego, co można wykorzystać jako „środek” dla doskonalenia jednostki. To „sfałszowanie” wolności przekłada się później na myślenie o relacji przestrzeni prywatnej i publicznej w kategoriach separacji i rywalizacji.

Relatywizm przedstawia samego siebie jako warunek sine qua non wszelkiej wielokulturowości, a każda grupa roszcząca sobie pretensje do życia wedle prawdy staje się potencjalnym źródłem przemocy. Trzeba zrezygnować - jak mówił Jürgen Habermas - z idei osądzania innych pomysłów na życie albo z samej tolerancji. Szczęście osiąga się, wedle tej ideologii, unikając pytania o prawdę, którą traktuje się jako nieużyteczny i szkodliwy koncept, przyprawiający o ból głowy. W istocie jednak relatywizm staje się odpowiedzialny za większą przemoc niż ta, którą - jak twierdzi - chce usunąć z przestrzeni społecznej: ogłaszając się rzecznikiem „większości”, prowadzi do sytuacji, w której społeczeństwo żyje zgodnie z tym, co medialnie jest silniejsze, poddany inżynierii społecznej, a nie kryterium prawdy.

Z kolei fenomenem, który pozwala lepiej wniknąć w problem nieobecności Boga w społeczeństwie laickim, jest tzw. now y at e izm. Skupia on naukowców, głównie socjologów, biologów, filozofów, którym wspólna jest idea totalności wiedzy naukowej, sprawiającej, że hipoteza Boga staje się niepotrzebna (co jako pomysł intelektualny nie jest niczym nowym) ${ }^{51}$. Po raz pierwszy określenie „nowy ateizm” pojawia się w 2006 roku w jednym

51 Por. É. Boné, Bóg, niepotrzebna hipoteza?, przekł. W. Szymona, Kraków 2004. 
z artykułów w czasopiśmie „Wired” ${ }^{52}$. Wobec zakładanego obskurantyzmu religii ruch określa się jako Bright (świetliści, inteligentni) ${ }^{53}$. Opierając się na naturalizmie i darwinizmie, prowadzi debatę filozoficzną, w której stara się udowodnić, że świat staje się wyjaśnialny bez Boga. W wielokulturowej konfiguracji społecznej „nowy ateizm” staje się podbudową ideologiczną, która ma usprawiedliwiać dogmatyczny relatywizm, choć paradoksalnie przyczynia się do tego, że pojmowanie wolności, tak przecież cennej dla ideologii laickiej, zostaje zakute w kajdany skrajnego ewolucjonizmu i tyranię „przypadku” czy „ślepego zegarmistrza”.

\subsection{Chrześcijanie hiszpańscy - nowi mozarabowie?}

Analizując wyzwania stojące przed dzisiejszym społeczeństwem hiszpańskim, trudno nie dostrzec wyraźnej analogii do czasów mozarabskich, w których chrześcijanie ponownie stają wobec imperatywu przyjęcia roli „niespokojnej mniejszości”. W dobie systematycznej, choć cichej ateizacji społecznej dokonującej się na Półwyspie Iberyjskim, która wyraża się w banalizowaniu wartości tradycji religijnych jako takich, troska o tożsamość wysuwa się na pierwszy plan. Mozarabowie znaleźli się w podobnej sytuacji przed wiekami: multikulturalizm najeźdźców, wynikający z kalkulacji politycznej, wedle której nie opłacała się droga konfrontacji, był w istocie ukrytym totalitaryzmem, który zmierzał do całkowitej arabizacji prowincji.

Jednym z obrazów, które oddają współczesny klimat, w jakim znaleźli się hiszpańscy chrześcijanie, może być metafora „zderzaka” Europy, niekiedy rozwijana również w kontekście polskim, w klasycznym rozumieniu „przedmurza”, które ochrania tożsamość będących „wewnątrz”. „Zderzak” przyjmuje na siebie siłę pierwszego uderzenia, starając się nie dopuścić do innych skutków, doprowadzając do sytuacji wytracenia siły starcia. Tym razem, można zaryzykować stwierdzenie, chrześcijanie hiszpańscy stali się

52 Szerzej na temat genezy całego ruchu: H. Schulz, Alter Wein in neuen schläuchen oder der Siegezug des Trivialen. Zur Kritik des sogenannten Neuen Atheismus, „Theologische Literaturzeitung” 135 (2010), s. 1-20.

53 R. A. Varghese, The „new atheism”: a critical appraisal of Dawnikns, Dennett, Wolpert, Harris and Stenger, [w:] A. Flew, There is a God. How the world's most notorious atheist changed his mind, San Francisco 2007, s. 161-183. 
właśnie takim duchowym „zderzakiem”, który staje w obliczu nowych wyzwań, przybierających postać multikulturalizmu, ale niecechującego się szacunkiem dla tożsamości podmiotów i ich aspiracji do poszukiwania prawdy, i w ten sposób kształtowania swojej wolności. Ma oznaczać zrezygnowanie ze świadectwa jako pewnej drogi do głoszenia prawdy. Nowa laickość nieuchronnie musi uderzyć w „chrześcijański zderzak”, bo nie da się głosić wolności do wyrażania swoich opinii i przekonań, a jednocześnie dozować jej wedle miary poprawności ideologicznej.

Via mozarabica staje się w ten sposób paradygmatyczną drogą czuwania nad przestrzenią, w której kultywuje się konstytutywne dla tożsamości sprawy. To denuncjowanie totalitarystycznych aspiracji pewnych ideologii (przed czym ostrzegał już przed wieloma laty Jan Paweł II), które pojawiają się w kamuflażu modnych i nowoczesnych poglądów. Bez wątpienia „nowa laickość”, której rezultatem jest specyficzna „chrystianofobia”, jest tego najlepszym przykładem.

\section{Dwa filozoficzne klucze, czyli o „granicach” i „wzajemności”}

Wychodząca z doświadczenia ogólnoludzkiego „graniczność” była w historii czynnikiem twórczym ${ }^{54}$. Wzniecała pasję. Pasję wiary, którą można streścić w jednym określeniu: być chrześcijaninem za wszelką cenę. W morzu dominującej kultury islamskiej w dawnych epokach, podczas rozszalałych w Europie burz rewolucji, zaślepienia ciekawostkami - być wiernym. $\mathrm{Na}$ styku kultur, gdzie Iberia znajdowała się przez wieki, celem było nie zagasić pasji bycia sobą, smakowania swego dziedzictwa. Nie zadowalała mozarabów zwykła koegzystencja, nie stali się niewolnikami przywilejów i nagród. Ich etos rodzi się jako ideał, który nie ma „prawie” nadziei na zrealizowanie się; który potrzebuje przeświadczenia o plus ultra dla nadziei. Odnalazł go w sercach i umysłach mozarabów, którzy zajęli ciekawą postawę wobec wyzwania wielokulturowości.

${ }_{54}$ Por. Granice i ograniczenia. O doświadczeniu granici ich przekraczaniu, red. M. Szulakiewicz, Toruń 2009 (zwł. Granice jako problem wspótczesnej kultury, s. 7-18). 
Współcześnie jednak multikulturalizm przyjmuje nazbyt często postawę skrajnie relatywistycznąi bywa łatwą receptą na zrównanie wszystkich kultur w duchu panującej prawomyślności, tracąc tym samym swoją wiarygodność (bo sugeruje istnienie jakiegoś kryterium pozakulturowego, którego jednak nie wskazuje, nie podejmując się refleksji zamiast charakterze ogólnym). Dlatego zamiast sprzyjać integracji opartej na uznaniu wartości i „roz-poznaniu”, traktuje wielość kulturową jako „sąsiedztwo obojętne”, czasem wrogie, prowadząc w gruncie rzeczy do jeszcze większej alienacji. Brakuje w zaj e m n o ś c i - kategorii zasługującej na szeroką refleksję filozoficzną, socjologiczną i teologiczną, którą w XX wieku podjął m.in. Maurice Nédoncelle ${ }^{55}$.

Ową wzajemność trzeba jednak widzieć w kontekście świadomości znaczenia i roli „granicy”, a więc postrzegać egzystencję ludzką nie w sposób wyizolowany, lecz we współ-dzieleniu, „wzajemności świadomości” ${ }^{56}$.Określamy się przez naszą relację do innych, a nie przez zamknięcie. Człowiek jest egzystencją zwróconą ku innym, stawiającą czoła sytuacjom, stającą się sobą pośród zjawisk ${ }^{57}$. Ta „wzajemność” zakorzenia się w postaci sprawiedliwości, która opiera się na mutua datione et acceptione ${ }^{58}$. Wzajemność zawsze jest związana z ryzykiem, że spotka się z oportunistą, który jest nastawiony tylko na branie, ale mimo to nie rezygnuje z tego pierwszego kroku, którym jest dar dla drugiego. W ten sposób rodzi się braterstwo, pewien „nowy humanizm” oparty na logice nie tyle „transakcji”, ile daru i odpowiedzi na dar.

\section{Podsumowanie}

Z całą pewnością ideał homo reciprocus nie był obcy również mozarabom, którzy realizowali go w czasach odległych. Ale ich niełatwy kazus jest bez wątpienia w jakiejś mierze paradygmatyczny. Nie poddając się pokusie ła-

55 M. Nédoncelle, La reciprocidad de las conciencias: ensayo sobre la naturaleza de la persona, Madrid 1997.

56 Por. V. Soldevila, El logos de la accíon: la reciprocidad de las conciencias: breve estudio de la dinámica de la acción en Maurice Nédoncelle, [w:] Logos dell'agape, s. 401-408.

${ }_{57}$ Por. L. Reygadas, Distinción y reciprocidad. Notas para una antropología de la equidad, „Nueva Antropología: Revista de Ciencias Sociales" 69 (2008), s. 9-31.

58 Summa theologica, I, q. 21, a. 1c. 
twego izolacjonizmu, stawiają na relacje z nową kulturą arabską, biorąc za podstawę troskę o własną tożsamość. To gotowość do intelektualnego dialogu i braterstwa, które nie odbywa się jednak za cenę zdrady wartości.

Homo se habet sicut homo ${ }^{59}$, by człowiek miał się za człowieka - to antropologiczne przesłanie Akwinaty, będące sercem komentarza do Psalmów, ostatniego komentarza biblijnego, który wygłosił w Neapolu na kilka miesięcy przed swoją śmiercią. Ale Super Psalmos, gdzie pojawia się to sformułowanie, to jednocześnie pewien ambitny i nad wyraz aktualny projekt niezacierania różności i godności osoby w dobie wielokulturowości. Tomaszowy projekt humanizmu, podobnie jak modus operandi mozarabów, opiera się bowiem nie tylko na tajemnicy wcielenia, ale także na nadziei ${ }^{60}$ : na ciągłym „nawracaniu się na nadzieję”.

59 Tomasz z Akwinu, Super Psalmum XXXI, n. 9.: „Si homo se habet sicut homo, Deus tractat eum sicut hominem, monitionibus et doctrinis; sed quando recedit a dignitate hominis, tractatur sicut brutum animal, quod coercetur poenis et violentia".

60 D. Doyle, The promise of Christian humanism: Thomas Aquinas on hope, New York 2011. 


\section{Summary}

\section{Mozarabs and Iberian experience of boundary}

Mozarabs who defended their Christian identity in exceptional circumstances, historical and cultural after 711 (the year of Arab invasion to the Iberian Peninsula) may become an interesting contribution to the contemporary debate on multiculturalism and its weaknesses. In many of the euchological texts the Spanish liturgy an excellent picture of the struggle for identity. The author of the article analyzed one of the Hispanic mass called Pro tribulatis emphasizes the need to care for own consciousness. Intersubjectivity making by the liturgy understood as an exchange, commercium, and reliance on tradition understood as a creative continuation, transfer, became the foundation of attitudes of mozarabic Christians. Based on the background of historical reflection, the article intend to rethink the difficulties observed in contemporary Spain, influenced by the "new secularism". Model of multiculturalism, is for many thinkers no longer sufficient and requires a strong correction.

Kewords: mozarabs, hispanic liturgy, eucology, multiculturalism

\section{Mozarabowie a iberyjskie doświadczenie graniczności}

Historia mozarabów, którzy bronili swej chrześcijańskiej tożsamości w wyjątkowych okolicznościach historycznych i kulturowych po 711 roku (inwazja arabska na Półwysep Iberyjski), może stać się ciekawym przyczynkiem do rozważań nad multikulturalizmem i jego słabościami. Doskonały obraz walki o tożsamość pozostawiła liturgia hiszpańska, która w wielu tekstach euchologicznych (choćby analizowana w artykule msza pro tribulatis) podkreśla konieczności troski o własną świadomość. Intersubiektywność dokonująca się w liturgii rozumianej jako wymiana, commercium, a także oparcie na tradycji będącej twórczą kontynuacją, przekazywaniem, stały się fundamentem postawy mozarabów. Na kanwie historycznych opisów artykuł omawia trudności, z którymi boryka się współczesna Hiszpania w dobie „nowego laicyzmu”. Model multikulturalizmu okazuje się dla wielu myślicieli już niewystarczający i wymagający zdecydowanej korekty.

Słowa kluczowe: mozarabowie, liturgia hiszpańska, euchologia, multikulturalizm

\section{Bibliografia}

Alarcón E., Sepulcrum Iacobi, [w:] Camino de Santiago - nie tylko droga. Historia i wspótczesność Szlaku św. Jakuba w Polsce, red. P. Roszak, Toruń 2012², s. 87-102.

Barkai R., Cristianos y musulmanes en España medieval (El enemigo en el espejo), Madrid 1984.

Brague R., Il futuro dell'Occidente, Milan 1998. 
Catlos B. A., The victors and the vanquished:Christians and Muslims of Catalonia and Aragon, 1050-1300, Cambridge 2004.

Diaz M., Los mozárabes. Una minoría combativa, [w:] C. Aillet, M. Penelas, P. Roisse, ¿Existe una identidad mozárabe? Historia, lengua y cultura de los cristianos de al-Ándalus (siglos IX-XII), Madrid 2008, s. 1-8.

Doubleday S. R.; Coleman D., In the light of medieval Spain: Islam, the West, and the relevance of the past, New York 2008.

Doyle D., The promise of Christian humanism: Thomas Aquinas on hope, New York 2011.

Boné É., Bóg, niepotrzebna hipoteza?, przekł. W. Szymona, Kraków 2004.

Fernández del Riesgo M., El papel del cristianismo en la configuración de la identidad europea ante el reto de la secularización y del multiculturalismo, „Ciencia Tomista” 3 (2011), s. 599-628.

Fuchs B., Exotic nation: maurophilia and the construction of early modern Spain, Philadelphia 2009.

Gallego M. A., The languages of medieval Iberia and their religious dimension, „Medieval Encounters" 1 (2003), s. 107-139.

García Gomez-Heras J. M., Un paseo por el laberinto. Sobre política y religión en el diálogo entre civilizaciones, Madrid 2008.

Gesché A., Przeznaczenie, przeł. A. Kuryś, Poznań 2006.

Gómez I., Nota en torno a los „Orígenes del culto de Santiago en España”, „Hispania Sacra” 7 (1954), s. 487-490.

Granice i ograniczenia. O doświadczeniu granic i ich przekraczaniu, red. M. Szulakiewicz, Toruń 2009.

Gutierez E. L., Los Mártires de Córdoba y la política anticristiana contemporánea en Oriente, „Revista de Estudios Árabes” 15 (1994), s. 453-462.

Hitchcock R., Mozarabs in medieval and early modern Spain: identities and influences, Burlington 2008.

López Gómez M., The Mozarabs: worthy bearers of Islamic culture, [w:] S. K, Jayyusi, The legacy of Muslim Spain, Leiden 1992, s. 171-175.

Lopez J. M., La educación intercultural como ejercicio de educación en valores, „Estudios Sobre Educación" 10 (2006), s. 9-36.

Makki M. A., El islam frente a las minorias cristianas, [w:] Actas de la I Jornada de Cultura Islamica „Al-Andalus, ocho siglos de la historia”, Toledo 23-26 de abril de 1987, Madrid 1989, s. 43-50.

Milbank J., Multiculturalismo en Gren Bretaña: el caso del reciente debate sobre la sharia, [w:] J. Prades, M. Oriol, Los retos del multiculturalismo. En el origen de la diversidad, Madrid 2009, s. 247-266.

Nédoncelle M., La reciprocidad de las conciencias: ensayo sobre la naturaleza de la persona, Madrid 1997.

Peñarroja L., Cristianos bajo el Islam: los mozárabes hasta la Reconquista de Valencia, Madrid 1993.

Pinell J., Pons J., La estructura de la misa en rito hispánico, herencia de la tradición universal y de su propia historia, „Notitiae” 267 (1988), s. 471-727.

Raley H., The spirit of Spain, Houston 2001. 
Ratzinger J., Bóg i świat. Wiara i życie w dzisiejszych czasach. Z kardynałem Josephem Ratzingerem - Benedyktem XVI rozmawia Peter Seewald, przekł. G. Sowinski, Kraków 2005.

Reygadas L., Distinción y reciprocidad. Notas para una antropología de la equidad, „Nueva Antropología: Revista de Ciencias Sociales" 69 (2008), s. 9-31.

Roszak P., Mozarabowie - niespokojna mniejszość. Liturgia mozarabska jako projekt duchowości czasów „bycia w mniejszości” w kontekście „Brewiarza Gotyckiego”, „Teologia i Człowiek” 13 (2009), s. 79-98.

Sánchez Cañizares J., Non possumus. Refleksje o współczesnej sytuacji moralnej w Hiszpanii, [w:] Dysputy Nawarryjskie w Toruniu, red. P. Roszak, Toruń 2010, s. 25-40.

Schulz H., Alter Wein in neuen Schlauchen oder der Siegezug des Trivialen. Zur Kritik des sogenannten Neuen Atheismus, „Theologische Literaturzeitung” 135 (2010), s. 1-20.

Scola A., Una nueva laicidad, Madrid 2007.

Soldevila V., El logos de la accíon: la reciprocidad de las conciencias: breve estudio de la dinámica de la acción en Maurice Nédoncelle, [w:] L. Granados, J. J. Pérez Sorba, Il logos dell'agape. Amore e ragione come principi dell'agire, Cantagalli 2008, s. 401-408.

Śnieżyński K., Pamięć w myśleniu religijnym. Kultura wspominania, zapominania i nadziei, „Analecta Cracoviensia” 42 (2010), s. 87-112.

Varghese R. A., The „New Atheism”: a critical appraisal of Dawnikns, Dennett, Wolpert, Harris and Stenger, [w:] A. Flew, There is a God. How the world's most notorious atheist changed his mind, San Francisco 2007, s. 161-183. 